E $\begin{aligned} & \text { Green giant } \\ & \text { The world's largest } \\ & \text { single-dish telescope } \\ & \text { is unveiled } \\ & \text { p816 }\end{aligned}$

\title{
UK government backs change in law over stem-cell research...
}

David Dickson, London

\& Paul Smaglik, Washington

The British government last week urged the country's research councils to draw up a programme of research into the potential therapeutic benefits to be derived from using human embryonic stem cells to replace diseased or damaged tissue.

At the same time, it has recommended that parliament modify an act passed ten years ago, which already permits research on embryos up to 14 days old, to allow embryo stem-cell research to take place in the United Kingdom.

But the government will allow members of parliament a free vote on the issue - a relatively unusual move in a political system where most votes take place along political lines. And, in a bid to draw a firm line between what is and what is not permitted, it has also promised new legislation explicitly outlawing the reproductive cloning of human beings.
The move comes as the US National Institutes of Health prepares to issue guidelines - expected by some in the next few days on the conditions under which it is prepared to finance human embryonic stem-cell research. But the longer term future of federal funding of such research hinges on the outcome of the US presidential campaign.

The British moves have brought protests from the country's vocal anti-abortion lobby which, like its counterpart in the United States, is arguing that the same goals could eventually be achieved through research using adult stem cells, thus, they claim, avoiding the need to use embryos.

Elsewhere in Europe, the reaction was equally mixed. Although the Vatican, perhaps predictably, issued a highly critical statement on the moral implications, others offered a milder rebuke to the British government for seeking to press ahead unilaterally with a 'functionalist' approach to embryonic

\section{... but Germany remains unmoved}

Quirin Schiermeier, Munich Britain's support for research on cloned stem cells from human embryos (see above) presents Germany with a dilemma. Although neither politicians nor research organizations are seeking changes to Germany's restrictive embryoprotection law, both know the implications of such research taking place in a nearby country.

They are also relaxed at the prospect, however. For if British research shows that scientific techniques banned in Germany can lead to new medical treatments, Germany's attitude may no longer be easy to justify, they say.

But not everyone is convinced of the medical potential of embryonic stem cells. "Medical breakthroughs are not in sight," says Wolf-Michael Catenhusen,

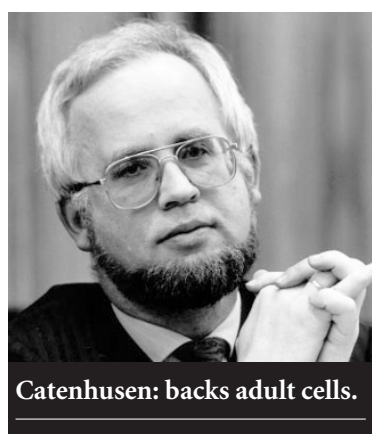

state secretary for research in the federal science ministry. "Our primary goal therefore remains to develop new therapies by using human adult stem cells."

The Deutsche

Forschungsgemeinschaft (DFG), which funds most German university research, already supports work on adult stem cells under one of its priority programmes. Like the government and the German Chambers of Physicians, the DFG sees no need to relax the embryo-protection law, aware of opposition from ethicists and theologians and widespread public hostility to the cloning of human embryonic stem cells.

"The mere expectation of new medical treatments is an insufficient justification," says Dietmar Mieth, head of the Centre for Ethics in Science at the University of Tübingen.

Others disagree. Given that both abortion and research on aborted fetuses are legal in Germany, "it is absurd that protection of embryos in culture is stronger than of those in utero," says Davor Solter, director of the Max Planck Institute for Immunobiology in Freiburg.

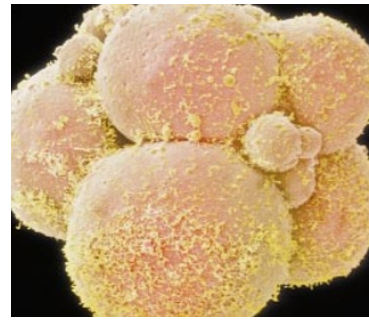

Huge potential: embryonic stem cells could revolutionize medicine.

stem-cell research, rather than trying to achieve a Europe-wide consensus first.

In general, the government's move has met with approval both in Britain - where only one newspaper, the conservative Daily Telegraph, published a critical editorial and abroad, where it has been widely welcomed as a pragmatic effort to balance ethical concerns for the treatment of embryos against the medical benefits likely to emerge from the research.

The decision came in response to proposals contained in a report drawn up over the past year by a panel headed by chief medical officer Liam Donaldson. This followed earlier recommendations to allow embryonic stem-cell research, leading eventually to 'therapeutic cloning', from both the Human Fertilisation and Embryology Authority and the Human Genetics Advisory Commission, subsequently endorsed by the Nuffield Council on Bioethics (see Nature 404, 697; 2000).

In announcing that the government had accepted his panel's proposals, Donaldson noted that although the possibility of 'reprogramming' adult cells was the 'Holy Grail' of stem-cell research, at present the use of either adult or fetal cells "are thought to be of more limited potential". He added: "It is partly a question of exploiting embryonic stem cells and seeing their potential, but also about resolving some of the theoretical, technical and safety questions."

It is thought that between five and six research groups in Britain are contemplating applying for funding for such research. The Donaldson report also calls for consideration of establishing collections of stem cells for research use, and the government has called on the research councils to do this. http://www.doh.gov.uk/cegc 